\title{
Diatom dan Paleolimnologi: Studi Komparasi Perjalanan Sejarah Danau Lac Saint-Augustine Quebeq-City, Canada dan Danau Rawa Pening Indonesia
}

\section{Diatom and Paleolimnology: Comparation Study of Historical Lakes Lac Saint- Augustine Quebeq-City, Canada and Rawa Pening Indonesia}

\author{
Tri Retnaningsih Soeprobowati ${ }^{1}$ dan Suwarno Hadisusanto ${ }^{2}$ \\ ${ }^{1}$ Jurusan Biologi FMIPA, Universitas Diponegoro, Tembalang, Jl Prof. Soedarto. SH, Tembalang, Semarang \\ E-mail: trsoeprobowati@yahoo.co.id *Penulis untuk korespondensi \\ ${ }^{2}$ Fakultas Biologi Universitas Gadjah Mada, Yogyakarta
}

\begin{abstract}
Diatoms are a micro-alga dominates in the aquatic ecosystem. Their silicious cell wall able to preserve death diatoms in the sediment for long periods of time, therefore, diatoms have an important role in the paleolimnological analysis. Diatoms assemblages in the sediment layer express the water quality whenever the diatom lives. This article provides information how to apply diatom on the paleo-limnological analysis, supporting with the case study in the Lac Saint-Augustine Quebec-City Canada and Rawa Pening Lake Indonesia. Modern diatom and the water quality from spatial and temporal range are used as a calibration set. The diatoms of below layers, then, Weighted Averaging (WA) with the calibration set to reconstruct the water quality in the past. Previously, both in Canada and Indonesia, those lakes were oligotrophic and sharply change into eutrophic condition since a lot of human activities developed around the lakes (anthropogenic factors). Naturally, the maturity of lake can not avoid and the succession had been fast by eutrophication. Paleolimnological approach provides baseline data in the past to develop the appropriate lake management.
\end{abstract}

Key words: diatoms, paleolimnology, eutrophication

Diterima: 29 Juli 2008, disetujui: 12 Januari 2009

\section{Pendahuluan}

Diatom merupakan mikroalga uniseluler yang distribusinya sangat universal di semua tipe perairan. Diatom merupakan penyusun utama fitoplankton baik di ekosistem perairan tawar maupun laut dengan jumlah spesies terbesar dibandingkan komunitas mikroalga lainnya. Diatom mempunyai kontribusi 40 $45 \%$ produktivitas laut sehingga lebih produktif dibandingkan dengan hutan hujan di seluruh dunia. Oleh karena itu tidak mengherankan apabila diatom mempunyai peranan yang sangat penting dalam siklus silika dan karbon di alam sehingga kesinambungan perikanan terjaga (Mann, 1999). Saat ini diketahui lebih dari 260 genus diatom hidup dengan lebih dari 100.000 spesies (Round et al., 2000).

Diatom mempunyai keunikan dan sangat spesifik, karena arsitektur dan anatomi dinding selnya yang tersusun dari silika, menyebabkannya dapat tersimpan dalam kurun waktu yang sangat lama di dalam sedimen.

Penelitian diatom berkembang sangat pesat dimulai tahun 1703 ketika mikroskop ditemukan, hingga ketika Battarbee (1986) menyatakan potensi diatom sebagai bioindikator kualitas lingkungan. Sejak tahun 1990-an penelitian tentang diatom sebagai bioindikator kualitas perairan banyak dilakukan 
di berbagai negara hingga aplikasinya dalam paleorekonstruksi perubahan lingkungan. Hal ini seiring dengan perkembangan implementasi analisis statistik multivariat untuk analisis paleorekonstruksi (Smol, 1990).

Potensi diatom sebagai bioindikator lebih baik dibandingkan dengan kelompok organisme yang lainnya. Keunggulan tersebut karena distribusi luas, populasi variatif, penting dalam rantai makanan, dijumpai di hampir semua permukaan substrat (mampu merekam sejarah habitat), siklus hidup pendek dan reproduksi cepat, banyak spesies sensitif terhadap perubahan lingkungan, mampu merefleksikan perubahan kualitas air dalam jangka pendek dan panjang, mudah pencuplikan; pengelolaan dan identifikasinya (Gell et al., 1999; Round et al., 2000). Hal tersebut di atas memberi nilai tambah potensi diatom untuk biomonitoring ekosistem akuatik yang telah dikenal di seluruh dunia (John, 2000). Pemanfaatan diatom sebagai bioindikator perairan telah banyak diimplementasikan. Potensi diatom sebagai bioindikator banyak digunakan pada kegiatan paleorekonstruksi perubahan lingkungan. Pada mulanya digunakan foraminifera karena dinding selnya tersusun dari karbonat yang dapat memfosil. Tetapi foraminifera hanya dijumpai pada habitat laut sampai perairan payau sehingga tidak dapat diimplementasikan untuk perairan tawar (Soeprobowati et al., 2000). Demikian juga Radiolaria berdinding sel dari silika yang dapat memfosil, tetapi habitatnya pada laut dalam (Haslett, 2002).

Diatom telah digunakan untuk merekonstruksi gempa bumi yang telah menginduksi tsunami 300 tahun lalu yang terjadi di pantai Selatan Washington. Diatom juga telah diaplikasikan dalam analisis paleoekologi di Everglades National Park, Florida Bay, USA (Pyle et al., 1998); analisis paleoekologi di Ealden Pond Massachussets, USA, Danau Lac Saint Augustine di QuebecCity Canada (Pienitz et al., 2006).

Paleolimnologi merupakan ilmu perairan tawar yang fokus pada interpretasi sekuen perlapisan sedimen dan proses diagenetik yang dapat mengubah rekaman tersebut. Tujuan kajian paleolimnologi adalah untuk memperoleh gambaran kondisi, perubahan parameter, produktivitas di masa lampau (Wetzel, 2001). Paleolimnologi termasuk ilmu multidisiplin karena memanfaatkan informasi fisik, kimia dan biologi yang tersimpan di dalam profil sedimen untuk kegiatan rekonstruksi kondisi lingkungan di masa lampau khususnya perairan darat. Lebih luas lagi, paleolimnologi mengkaji tentang perubahan jangka panjang pada geomorfologi basin danau (Smoll, 2008). Pendekatan paleolimnologi sangat penting karena sangat efektif untuk menjawab permasalahan kualitas air. Dengan mengetahui kualitas perairan di masa lampau dapat memprediksi kualitas perairan di masa mendatang. Sejarah tidak hanya sekedar menceritakan kembali masa lampau, tetapi juga mempunyai makna yang lebih dalam sebagai pengingat dan pemeringat. Oleh karena itu maka paleolimnologi merupakan ilmu yang mempelajari masa lampau untuk menemukan masa depan dengan mempelajari sejarah kharakteristik dan sifat perairan tawar, meliputi fisik, kimia, biologi, geografi, dan hidrologi yang tersimpan dalam inti sedimen.

Bioindikator untuk rekonstruksi harus organisme yang memiliki dinding sel yang tidak terdegradasi pada saat organisme mati dan mengendap. Permasalahan muncul, bagaimana diatom yang tersimpan dalam perlapisan sedimen mampu menguak perjalanan sejarah danau?

Permasalahan tersebut akan terjawab dalam artikel ini karena disusun dengan tujuan memberikan informasi peranan diatom dalam paleolimnologi, khususnya dalam mengungkap perubahan kualitas perairan danau dalam perjalanan waktu. Naskah ini mengungkap fakta tersebut dilengkapi dengan studi komparasi aplikasi diatom dalam analisis paleolimnologi dampak aktivitas manusia terhadap ekosistem lentik khususnya di Danau Lac Saint-Augustine (Canada) yang dilakukan oleh Pienitzs et al., (2006), yang memiliki kesamaan dengan danau di Indonesia yang ada di daerah sub urban seperti Danau Rawa Pening. Studi kasus ini diharapkan dapat menjadi sumber informasi mendasar yang dibutuhkan oleh pengelola dan peneliti perairan sebagai landasan preservasi dan restorasi pengelolaan danau. 


\section{Metode Penelitian}

Bahan yang digunakan adalah hasil penelitian diatom di Danau Rawa Pening (Indonesia) dan danau subtropis (Canada). Metode yang digunakan dalam kajian ini membandingkan kondisi danau di daerah suburban Canada dan Indonesia. Data diatom dan kualitas air di Danau Lac Saint-Augustine Quebec Canada berasal dari Pienitzs et al., (2006), dan Danau Rawa Pening (Jawa Tengah) diambil dari data Soeprobowati et al., (2005). Pembandingan dilakukan secara deskriptif kualitatif, meskipun datanya adalah kuantitatif.

\section{Hasil dan Pembahasan}

Analisis paleolimnologi pada umumnya dilakukan berdasarkan pengkajian informasi aspek biologi, kimia dan fisika yang terekam dalam sedimen. Kehandalan diatom sebagai bioindikator perubahan lingkungan mampu memberikan bukti bahwa aktivitas manusia merupakan faktor dominan yang menyebabkan adanya perubahan tersebut. Kualitas air di Danau Lac Saint-Augustine (Canada) mengalami deteriorasi serius, maka diambil kebijakan larangan olah raga air di danau ini pada musim panas seiring problem cyanobacteria bloom. Penelitian yang dilakukan Pienitz et al., (2006) mengungkapkan bahwa sebelum ada aktivitas manusia danau dalam kondisi oligotrofik, namun kemudian menjadi sangat eutrofik sampai kini. Untuk mendeterminasi penyebab eutrofikasi maka dilakukan analisis fosil diatom, pigmentasi, geokimia yang digunakan sebagai indikator kualitas air, dan rekonstruksi kecenderungan konsentrasi P-total.

Eutrofikasi menjadi problem perairan yang muncul seiring dengan perkembangan pertanian, industri dan urbanisasi. Hal ini dapat terjadi di perairan manapun. Problem menjadi semakin serius apabila terjadi di ekosistem lentik (tergenang) seperti danau dan waduk karena waktu tinggal bahan pencemar dan masa pemulihan di danau lebih lama dibandingkan di ekosisitem lotik (mengalir). Problem serupa juga banyak terjadi di Indonesia. Laju eutrofikasi meningkat dengan pesat di ekosistem perairan lentik di seluruh Indonesia yang cenderung membuat pendangkalan danau.

Paleolimnologi danau cukup dalam dan tidak terganggu oleh manusia dapat membuktikan bahwa danau dapat berubah dari oligotrofik menjadi mesotrofik dan kemudian eutrofik. Kondisi ini dapat kembali dari eutrofik menjadi mesotrofik dan oligotrofik. Siklus ini dapat terjadi berulang-ulang berkaitan dengan perubahan iklim regional (Horne dan Goldman, 1994). Pendekatan paleolimnologi dapat digunakan untuk mengkaji respon ekosistem danau terhadap reduksi nutrien (Battarbee et al., 2005). Hasil penelitian paleolimnologi dapat memberikan bukti bahwa banyak danau yang sangat dipengaruhi masukan nutrien, namun kebanyakan badan air secara alami merupakan perairan yang produktif, bahkan sebelum interfensi manusia (Smol, 2008).

Dalam analisis paleolimnologi, diperlukan informasi mengenai luas daerah tangkapan, renewal time, luas danau, kedalaman, kualitas air saat ini, dan kandungan klorofil. Data pendukung lain di Danau Lac Sant-Augustine juga diperlukan seperti dinamika populasi dan land use selama kurun lebih dari 100 tahun, sehingga dapat diketahui bahwa kenaikan populasi penduduk yang pesat sejak 1960 dan pembangunan highway pada 1977 berdampak pada eksplosi demografi. Hal tersebut didukung oleh foto udara pada 1937, 1953, 1987, dan 2002, sehingga perubahan land-use dapat diketahui secara cermat. Data base yang penting bagi pengelolaan wilayah seperti ini yang belum dimiliki oleh banyak ekosistem perairan di Indonesia.

Rekonstruksi perubahan lingkungan oleh faktor antropogenik dapat dilakukan melalui 8 tahapan: 1) Penentuan lokasi penelitian berdasarkan permasalahan yang spesifik pada lokasi tersebut. 2) Penentuan lokasi sampling harus representatif. 3) Pengambilan sampel sedimen pada lokasi terdalam dari danau yang mewakili profil perubahan danau. 4) Sub-seksi sampel sedimen dengan interval tertentu untuk keperluan digesti dan preparasi diatom. 5) Radioactive dating profil sedimen untuk mengetahui kronologinya. 6) Identifikasi dan penghitungan diatom pada tiap lapisan sedimen 
dilakukan dengan menggunakan mikroskop. 7) Interpretasi data untuk pengkajian lingkungan. 8) Aplikasi model kalibrasi terhadap lingkungan sehingga dapat diperoleh informasi kondisi lingkungan pada masa sekarang dan masa lampau (Gambar 1).

Untuk kasus di Danau Lac SaintAugustine, pencuplikan sedimen dengan corer sedalam $75 \mathrm{~cm}$ pada situs danau yang memiliki kedalaman maksimal yaitu $6,1 \mathrm{~m}$. Sampel sedimen setebal $76 \mathrm{~cm}$ kemudian disubseksi dengan interval $0,5 \mathrm{~cm}$ untuk sampel $0-30 \mathrm{~cm}$ dan interval $1 \mathrm{~cm}$ untuk sampel $35-76 \mathrm{~cm}$. Di Danau Rawa Pening pencuplikan dilakukan dengan core barrel yang dimodifikasi sedalam $30 \mathrm{~cm}$ pada lokasi dekat inlet danau. Sampel sedimen di sub-seksi $2 \mathrm{~cm}$ (Soeprobowati et al., 2005).

Korelasi dikerjakan antara diatom modern (lapisan atas) dan kualitas lingkungan (kasus eutrofikasi berdasar $\mathrm{N}$ - dan P-total perairan). Rekonstruksi konsentrasi P-total pada lapisan bawah dilakukan oleh Pienitzs et al., (2006) dengan membandingkan diatom modern - dari 81 danau dari negara bagian New England yang telah diukur kandungan P-total pada tahun 1991 dan 1994 dengan fosil diatom yang diperoleh dari penelitian. Diatom based inference model untuk merekonstruksi kandungan P-total berdasarkan fosil diatom secara Weighted Averaging partial least squares regression techniques. Analogi derajat keasaman antara modern (kalibrasi) dan fosil (core) diuji dengan Program ANALOG. Apabila sampel fosil memiliki koefisien dissimilaritas $<75 \%$ berbarti bagus, antara $75-$ 90\% kurang bagus dan yang lebih besar dari 95\% tidak ada analogi. Selanjutnya dengan progam CANOCO (Canonical Correspondence Aanalysis) untuk mengetahui ketepatan fosil untuk rekonstruksi variabel.

WA (Weigthed Averaging) adalah proses fungsi transfer untuk estimasi kualitas air atau kimia air berdasarkan diatom (Koster et al., 2004). Secara prinsip takson tertentu akan melimpah pada kondisi optimum untuk regenerasi dan nilai optimum variabel lingkungan dihitung mengacu rerata konsentrasi tiap lokasi. Tiap nilai variabel di weighted-kan dengan kemelimpahan jenis diatom. Estimasi konsentrasi variabel berdasarkan fosil diatom di lapisan sedimen dilakukan inversi dari persamaan WA-nya.

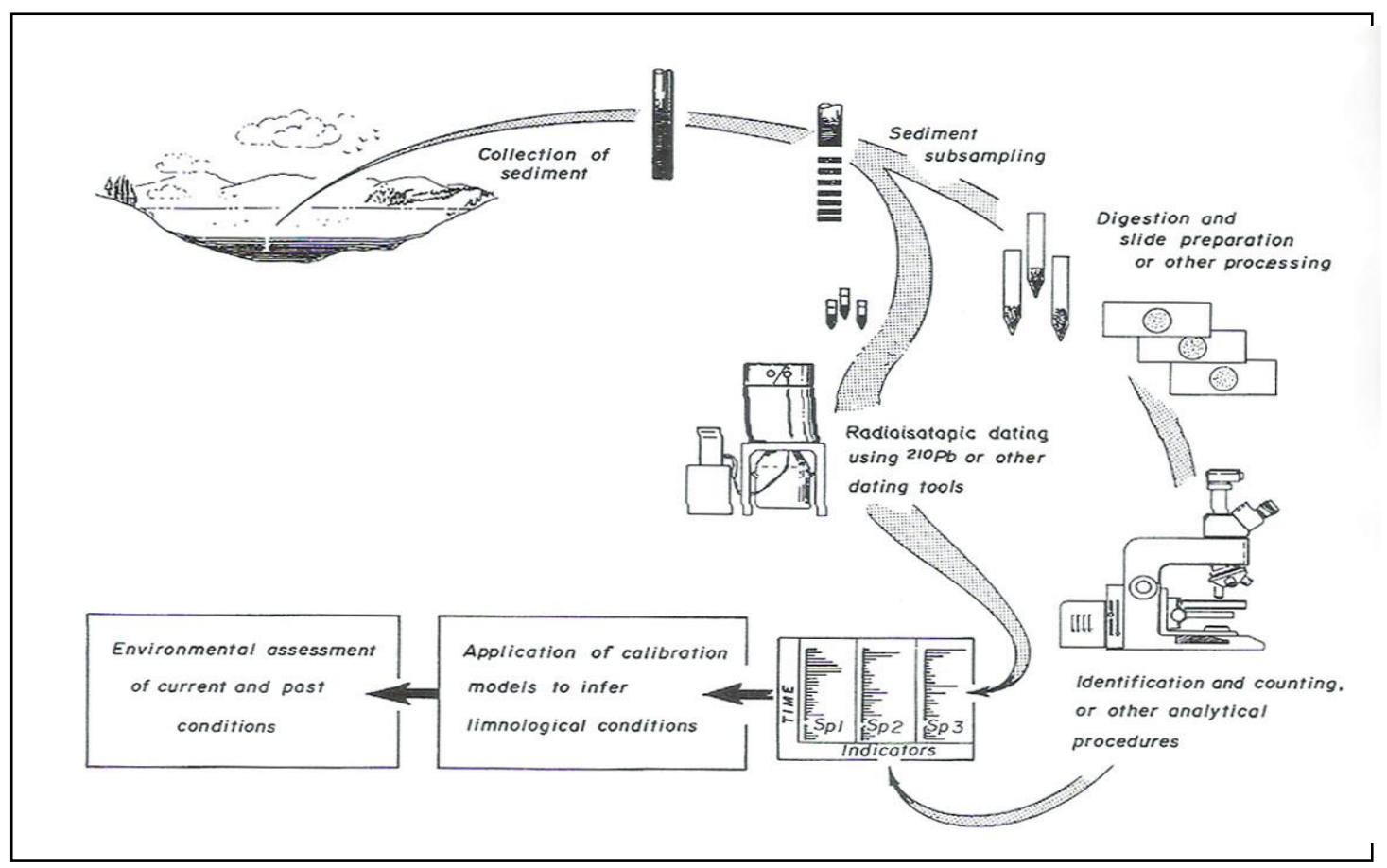

Gambar 1. Pendekatan paleolimnologi untuk kajian rekonstruksi perubahan lingkungan (Smol, 2008). 
Berdasar hasil analisis profil diatom, maka sampel Pienitzs et al., (2006) dapat dibagi tiga zona yang merupakan kecenderungan kondisi geofisik-kimia yang konsisten dengan periode sejarah dan aktivitas manusia di daerah tangkapan danau. Zona-1 merupakan periode sebelum/awal pengembangan pemukiman dan rekonstruksi kanal (1670 - 1750). Zona ini dapat dibagi menjadi dua sub-zona yaitu 1-a merupakan representasi periode sebelum dan awal kolonial dan 1-b merupakan periode konstruksi kanal (1748). Zona-1 terbentuk pada saat kondisi perairan oligo-mesotrofik dengan indikator diatom, konsentrasi pigmen, diatom-infered konsentrasi P-total dan elemen kimia lainnya.
Diatom pada zona ini adalah jenis yang mengindikasikan kondisi perairan oligo- dan mesotrofik antara lain: A. alpigena; $A$. ambigua; A. perglabra; Tabellaria flocculosa dan F. cappucina (Gambar 2.). A. ambigua dijumpai pada perairan mesotropik di Amerika Serikat dengan konsentrasi P $8-39 \mu \mathrm{g} / \mathrm{L}$ (Diatom Paleolimnology Data Coop, 2003). Konsentrasi diatom rendah pada zona-1, menunjukkan perairan kurang produktif dan pelarutan materi anorganik allokhtonus dominan. Hal ini didukung oleh rendahnya diatom-infered konsentrasi klorofil-a dan karotenoid (Gambar 3).

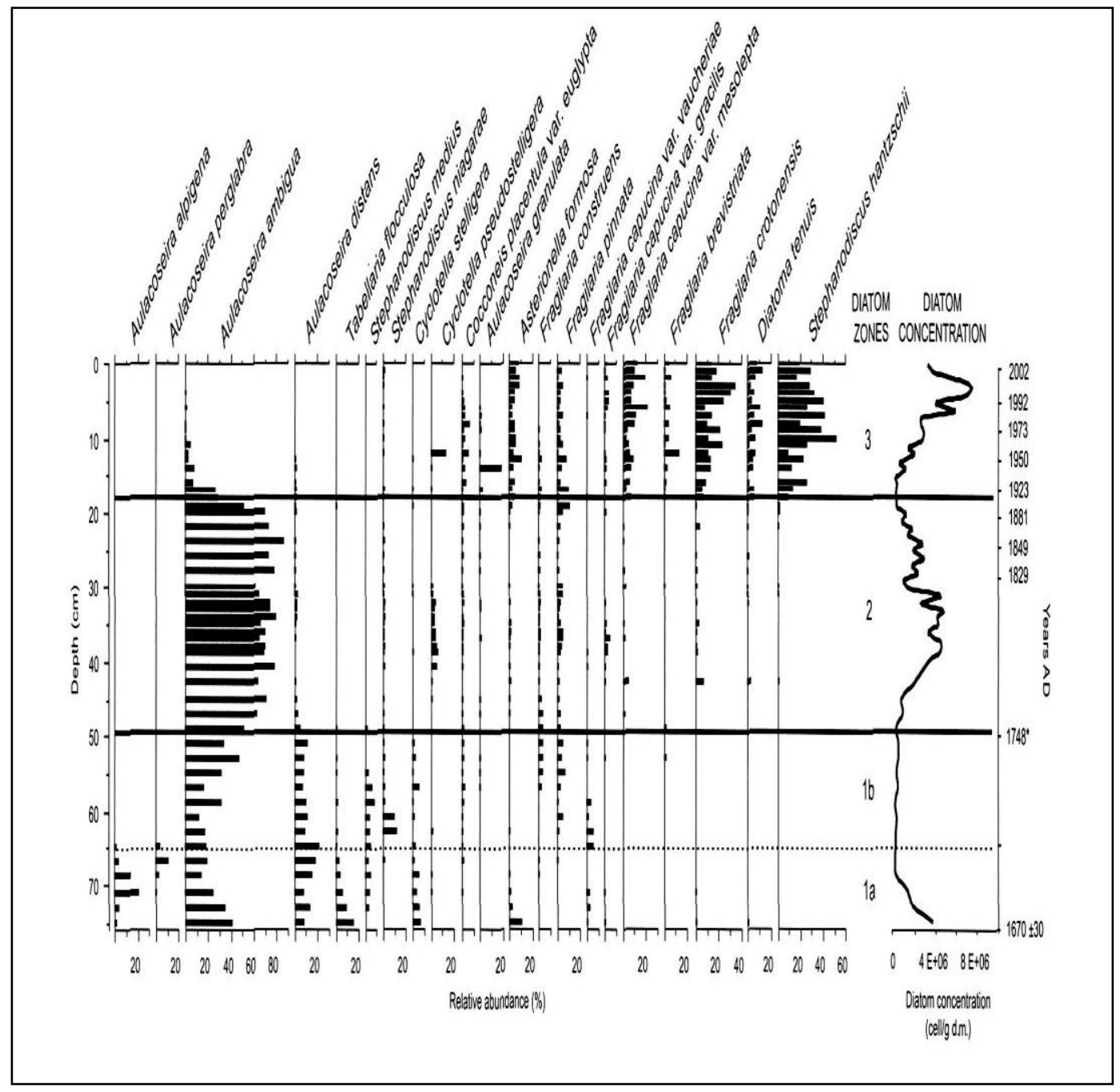

Gambar 2. Stratigrafi perubahan komposisi kumpulan diatom yang tersimpan dalam inti danau LacSaint-Augustine (Pienitzs et al., 2006). 


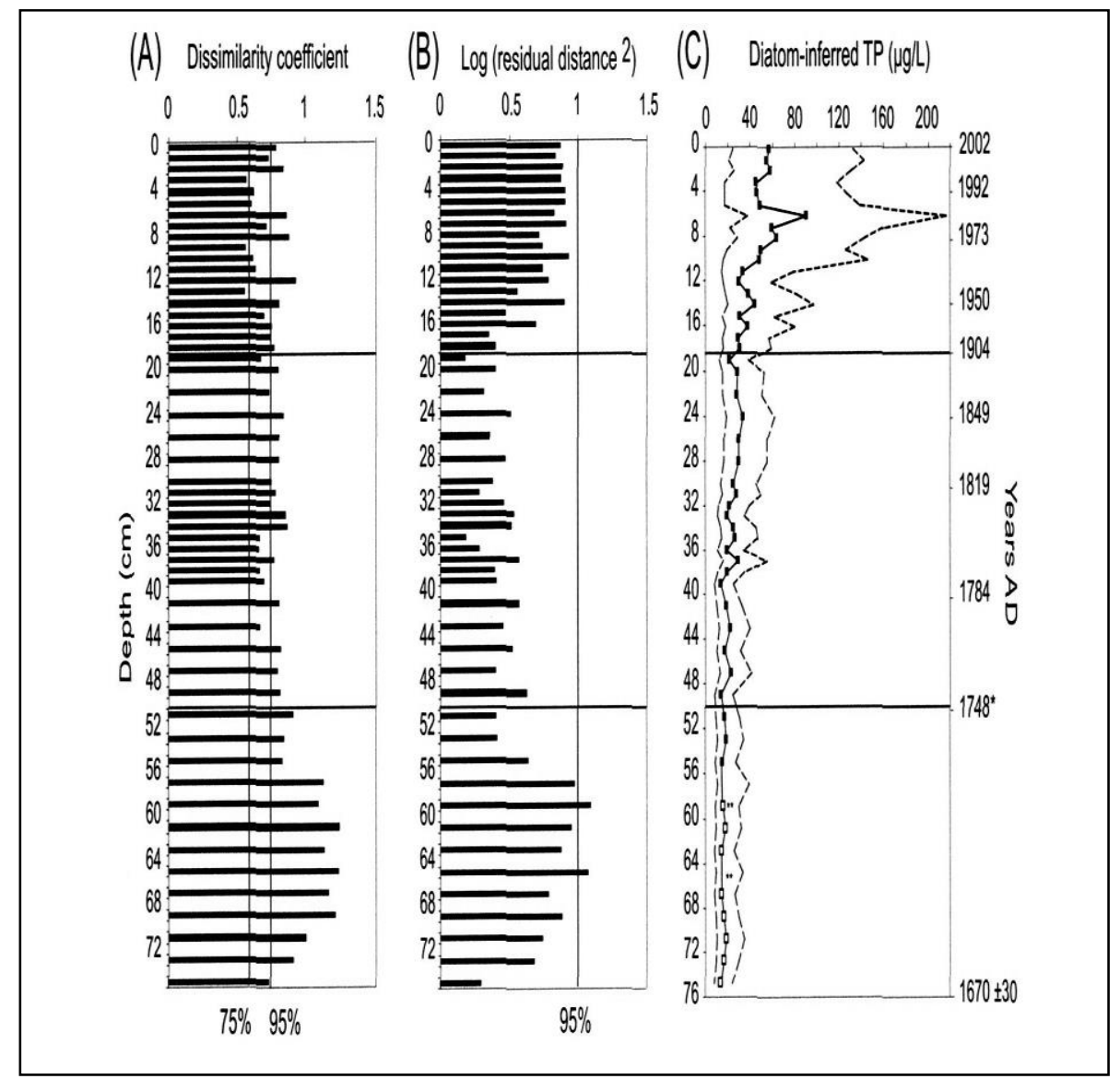

Gambar 3. Rekonstruksi perubahan lingkungan berdasarkan diatom-based infered P-total. A. Analog antara kumpulan diatom modern dan fosil. Persentase mengindikasikan kecukupan analog dengan kumpulan fosil. B. Besarnya residu yang dideterminasi melalui analisis canonikal koresponden terhadap keterbatasan total fosfor (TP). C. Infersi diatom dan konsentrasi TP (Pienitzs et al., 2006).

Pada Gambar 2, A. distans dominan hanya pada zona-1 mengindikasikan bahwa perairan dalam kondisi asam (Gell et al., 1999; Forel dan Grafe, 2002). Hal ini berarti bahwa dalam periode tersebut danau masih dalam kondisi asam yang biasa terjadi pada danau vulkanik.

Zona-2, (1750-1904), periode human settlement, ditandai oleh indikator biologi, fisik maupun kimia. Komunitas diatom masih relatif sama dengan zona-1 hanya kemelimpahan yang berbeda. Pada zona-1 A. ambigua yang hanya $40 \%$, pada zona ini menjadi $80 \%$ dan $F$. pinnata hampir $10 \%$. Konsentrasi klorofil-a dan karotenoid masih relatif rendah seperti di zona-1, mengindikasikan mesotrofik. Konsentrasi logam (Al, $\mathrm{Mg}, \mathrm{Fe}, \mathrm{Zn}, \mathrm{Pb}$ dan $\mathrm{Cu}$ ) mulai meningkat, mengindikasikan adanya peningkatan erosi tanah di daerah tangkapan akibat deforestasi.

Zona-3 merupakan periode pertanian, industri dan urban (1904-2002). Dampak antropogenik di daerah tangkapan terekspresikan nyata. Suksesi diatom mesotrofik berganti dengan melimpahnya diatom indikator perairan eu- dan hipertrofik seperti Stephanodiscus hantzschii (60\%), Asterionella formosa, F. crotonensis (5-15\%). Meningkatnya spesies diatom epifitik pada zona-3 merupakan indikasi kemelimpahan makrofita di zona litoral. Makrofita akan mendominasi perairan ketika fosfor rendah; fitoplankton melimpah saat konsentrasi fosfor meningkat 3 kali lipat, berarti kondisi eutrofik. 
Hal ini ditunjukkan munculnya diatom planktonik melimpah (S. hatzschii); konsentrasi diatom mencapai puncak pada 1992. Pertengahan abad 20 pupuk artifisial sangat tinggi di kawasan pertanian sekitar danau, peningkatan pemukiman yang ber-dampak pada problem limbah domestik dan septic-tank serta industri dan pembangunan highway berkontribusi terhadap peningkatan dampak antropengik pada danau. Hal ini diindikasikan oleh melimpahnya $S$. hantzscii yang merupakan bioindikator perairan tercemar berat oleh nutrien (eutrofik - hipertrofik) dan logam berat. Diatom meningkat, khususnya $S$. hantzschii berkorelasi dengan peningkatan kandungan klorofil-a dan karotenoid dalam sedimen.

Hal yang menarik di Danau Lac SaintAugustine adalah tidak dijumpainya jenis diatom payau sebelum abad 20, tetapi predominan (11\%) di 1970an, antara lain spesies Epithemia sorex, Cyclotella meneghiniana, dan Actinocyclus normanii. Kehadiran jenis diatom laut berkaitan dengan standar pemeliharaan jalan dan highway selama musim dingin dengan penggaraman.

Dimulai periode deforestasi, terdapat korelasi kenaikan diatom-inferred fosfor 1950an dengan meningkatnya produktivitas primer karena naiknya kandungan klorofil-a. Sejak 1938 kandungan karotenoid meningkat 100\%, diduga berkaitan dengan tersimpannya pigmen ini dalam kondisi anoksik atau dengan produktivitas primer. Mulai 1990, ada peningkatan fosfor dan zat besi di danau mengindikasikan aktivitas pertanian meningkat di kawasan tangkapan air. Pemanfaatan pupuk sintetis pasca PD-II mengakibatkan eutrofikasi sedangkan peningkatan konsentrasi logam berat sedimen merefleksikan perkembangan industri di Quebec City dan pembangunan highway. Lahan yang digunakan untuk pertanian di daerah tangkapan air hanya 20\%, sehingga degradasi kualitas air di Lac Saint-Augustin lebih berkaitan dengan peningkatan urbanisasi, pemukiman dan rekreasi.

Berdasarkan diatom di dalam sedimen, danau Lac Saint-Augustin pada 3 abad yang lalu dalam kondisi oligo-mesotropik. Perubahan menjadi eutrotrofik dipercepat oleh aktivitas manusia di danau maupun daerah aliran sungai. Penyebab eutrofikasi adalah masuknya nutrien terutama fosfor berkaitan dengan deforesasi dan urbanisasi di daerah tangkapan serta pertanian. Pengelolaan dan restorasi danau dilakukan dengan reduksi nutrien ke danau.

Belajar dari kasus Danau Lac SaintAugustin, maka rekonstruksi Danau Rawa Pening juga perlu dilakukan berbasis diatom. Kondisi eutropik Rawa Pening sekarang lebih banyak disebabkan oleh aktivitas manusia daripada secara alami. Hal ini perlu dilakukan untuk mengetahui kecenderungan perubahan kualitas air yang terjadi, sehingga menjadi landasan untuk pengembangan manajemen danau.

Secara alami Danau Rawa Pening terbentuk melalui proses letusan vulkanik yang mengalirkan larva basalt dan menyumbat aliran Kali Pening di Tuntang (Wardani, 2002). Sebagai akibatnya lembah Pening yang berhutan tropik menjadi rawa dan termasuk tipe "mangkok". Rekayasa teknik, dimulai pada 1916, pembangunan dam dikembangkan di hulu Sungai Tuntang (Goltenboth, 1994), berakibat permukaan air rawa naik. Penggenangan lembah tersebut membawa dampak besar terhadap perubahan ekosistemnya, seperti penggambutan sisa-sisa hutan tropik, invasi tumbuhan air, terbentuknya pulau terapung dan berkembangnya komunitas akuatik. Mulai sejak itulah terjadi perubahan yang semula merupakan danau alami berubah menjadi danau semi alami.

Berdasarkan topografi, Danau Rawa Pening terletak di daerah yang rendah dan dikelilingi oleh beberapa perbukitan dan gunung dengan slope berkisar antara 8\% hingga $>30 \%$, seperti Gunung Telomoyo (1.895 m), Gunung Butak (1.000 m), Gunung Balak (700 m), Gunung Payung dan Gunung Rong (600 m dpl). Kondisi ini menyebabkan air danau bertambah terus, sementara air yang keluar hanya sedikit. Penambahan air itu juga membawa material dari hulu yang kemudian diendapkan di danau, sehingga menambah endapan yang cukup besar. Seiring perjalanan waktu ada kecenderungan perubahan tipe basin menjadi tipe "piring". Secara ekologis, Danau Rawa Pening telah telah banyak mengalami perubahan karena perkembangan tumbuhan akuatik tidak terkontrol dan umumnya 
berkaitan dengan proses eutrofikasi. Kurang lebih 120 ha wilayahnya tertutup oleh Eichhornia crassipes, 20 - 50 ha oleh Hydrylla verticillata dan 100 ha oleh Salvinia cucculata (Lehmusluoto et al., 1995). Pada penelitian tersebut penutupan tumbuhan air di Danau Rawa Pening kurang lebih $41,5 \%$. Penutupan per-mukaan oleh tumbuhan air sekarang semakin besar prosentasenya, pada musim kemarau bisa mencapai 70\%. Pertumbuhan yang tidak terkendali ini muncul pulau terapung; pendangkalan akibat sedimen terperangkap di akar tumbuhan, dan akumulasi daun /seresah di dasar perairan.

Kualitas perairan Danau Rawa Pening jika dibandingkan dengan Lac Saint-Augustine, sama-sama eutrofik, tetapi konsentrasi $\mathrm{P}$ di Danau Rawa Pening masih 10 kali lebih rendah. Jenis diatom di Rawa Pening dan di Danau Lac Quebic yang sama ada $25 \%$. Kehadiran jenis diatom yang melimpah; $A$. granulata, A. ambigua, $F$. capucina, $F$. vaucheria mengindikasikan kondisi eutrofik seperti dijumpai di Danau Lac Quebic Canada pada zona 2 dan 3.

Sejak dimulai pembangunan pertama dam, Rawa Pening sebagai danau semi alami sudah berumur 92 tahun dengan kondisi kritis akibat pendangkalan yang dipercepat oleh proses eutrofikasi. Secara alami; melalui fenomena geologik maupun secara buatan melalui rekayasa rekonstruksi arsitektural, danau pasti mengalami maturasi dan akan mati secara cepat atau lambat. Namun eksistensi Danau Rawa Pening tergantung pada pemahaman semua pihak, bisa membuat segera mati atau berusaha mempertahankannya.

Danau Rawa Pening adalah bentang lahan yang permanen, sebagai landmark daerah Semarang, keberadaannya harus dilestarikan baik dari segi hidrologis, ekonomis, historis, ekologis, maupun sebagai model danau lestari.

\section{Kesimpulan}

Pendekatan paleolimnologi berbasis
diatom pada lapisan sedimen untuk
rekonstruksi perubahan lingkungan merupakan
salah satu tool yang dapat diaplikasikan dalam
menguak perjalanan sejarah danau. Diatom modern pada lapisan atas sedimen diinfersikan terhadap diatom death assemblages pada lapisan dibawahnya, maka dapat dilakukan rekonstruksi kondisi lingkungan pada saat diatom tersebut masih hidup. Informasi tentang perubahan kondisi lingkungan masa lampau ini sangat bermanfaat dalam upaya pengelolaan danau.

\section{Daftar Pustaka}

Battarbee, R.W. 1986. Diatom ana-lysis. Handbook of Holocene Paleoecology and Paleohydrology (edited by B.E. Berglund). John Wiley \& Sons, London.

Battarbee, R.W., Anderson, NJ., Jeppesen, E. and Leavit, P.R. 2005. Combining Paleolimnological and Limnological Approach in Asses Sing Lake Ecosystem Response to Nutrient Reduction. Freshwater Biology 50: 1772-1780.

Forel and Grafe. 2002. Using Diatom to Assess the Biological Condition of Large River. IDAHO USA. Fresh-water Biology 47: 2015-2037.

Gell, P.A., Sonneman, J.A., Reid, M.A., Ilham, M.A. and Sincock, A.J. 1999. An Illustrated Key to Common Diatom Genera from Southern Australia. CRC for Freshwater Ecology, Thurgoona, NSW.

Haslett, S.K. 2002. Palaeoceanographic Applications of planktonic Sarcodine Protozoa: Radiolaria and Foramnifera. In Quaternary Environmental Micropaleontology. Arnold, London.

Horne, A.J. and Goldman, C.R. 1994. Limnology. McGraw-Hill, Inc., New York.

Jamil, K. 2001. Bioindicator and BioMarkers of Environmental Pollution and Risk Assessment. Science Publishers, USA.

John, J. 2000. A Guide to Diatoms as Indicators of Urban Stream Health LWRRDC Occasional Paper 14/ 99 ,Urban Sub-Program, Report 7.

Koster, D.; J.M. Racca; and R. Pienitz. 2004. Diatombased inference models and reconstructions revisited: methods and transformation. Journal of Paleolimnology 32: 233 - 246.

Lehmusluoto, P. and Machbub, B. 1995. National Inventory of the Major Lakes and Reservoirs in Indonesia. Expedition Indodanau. Technical Report. ISBN 951-45-7237. Printed and bound by Painatuskeskus Oy Helsinki.

Mann, D.G. 1999. The Species Concept in Diatoms. Phycologia 38 (6): 437-495. 
Pienitzs, R., Robergem, K. and Vincent, W.F. 2006. Three Hundred Years of Human-Induced Change in an Urban Lake: Paleolimnological Analysis of Lac Saint-Augustin, Quebec City, Canada. Canadian J. of Botany 84: 303-320.

Pyle, L., Cooper, S.R. and Huvane, J.K. 1998. Diatom Paleoecology Pass Key Core 37, Everglades National Park Florida Bay. Open -File Report 98-522, USGS (US geological Survey).

Round, F.E., Crawford, R.M. and Mann, D.G. 2000. The Diatoms: Biology and Morphology of the Genera. $2^{\text {nd }}$. Cambridge University Press, UK.

Soeprobowati, T.R., Hidayat, J.W. and Baskoro, K. 2000. Zonation of Banjir Kanal Barat River Semarang, Based on Benthic Fora Minifers. $J$. Biota 5 (2): 71-80.

Soeprobowati, T.R., Rahmanto, W.H.T.R., Hidayat, J.W. dan Baskoro, K. 2005. Kajian Perubahan Ekosistem Danau Rawa Pening menggunakan Diatom sebagai Bioindikator. Lap. Penelitian, Lembaga Penelitian Universitas Diponegoro.
Smol, J.P. 1990. Paleolimnology: Recent Advances and Future Challanges. Me.Ist. Ital. Idrobio 47: 253-276.

Smol, J.P. 2008. Pollution of Lakes and Rivers A Paleoenvironmental Perspective. 2nd ed. Blackwell Publishing, USA.

Wardani, N.S. 2002. Sistem Geologi Rawa Pening. Paper dalam Sim- posium dan Lokakarya Pelestari an Danau Rawa Pening untuk Pemberdayaan Masyarakat. 18-19 April 2002. Pusat Studi Rawa Pening, Universitas Kristen Satya Wacana, Salatiga.

Wetzel, R.G. 2001. Limnology, Lake and River Ecosystems. 3rd ed. Academic Press, NY. 